\title{
Hyperimmune anti-COVID-19 IVIG (C-IVIG) Therapy for Passive Immunization of Severe and Critically III COVID-19 Patients: A structured summary of a study protocol for a randomised controlled trial
}

Shaukat Ali ${ }^{*}$, Shobha Luxmi ${ }^{2}$, Fatima Anjum³, Sheikh Muhammad Muhaymin ${ }^{1}$, Syed Muneeb Uddin', Ayesha Ali', Mir Rashid Ali', Sohaib Tauheed ${ }^{4}$, Mujtaba Khan ${ }^{1}$, Mohsin Bajwa², Saif Ullah Baig², Elisha Shalim', Iqra Ahmed', Abdul Samad Khan ${ }^{5}$ and Saeed Quraishy ${ }^{6}$

\begin{abstract}
Objectives: The aim of this trial is to investigate the safety and clinical efficacy of passive immunization therapy through Hyperimmune anti-COVID-19 Intravenous Immunoglobulin (C-IVIG: 5\% liquid formulation), on severe and critically ill patients with COVID-19.

Trial design: This is a phase I/II single centre, randomised controlled, single-blinded, superiority trial, through parallel-group design with sequential assignment. Participants will be randomised either to receive both C-IVIG and standard care or only standard care (4:1).

Participants: The study is mono-centric with the participants including COVID19 infected individuals (positive SARS-CoV-2 PCR on nasopharyngeal and/or oropharyngeal swabs) admitted in institute affiliated with Dow University Hospital, Dow University of Health Sciences, Karachi, Pakistan. Consenting patients above 18 years that are classified by the treating physician as severely ill i.e. showing symptoms of COVID-19 pneumonia; dyspnea, respiratory rate $\geq 30 / \mathrm{min}$, blood oxygen saturation $\leq 93 \%, \mathrm{PaO}_{2} / \mathrm{FiO}_{2}<300$, and lung infiltrates $>50 \%$ on CXR; or critically ill i.e. respiratory failure, septic shock, and multiple organ dysfunction or failure. Patients with reported IgA deficiency, autoimmune disorder, thromboembolic disorder, and allergic reaction to immunoglobulin treatment were excluded from study. Similarly, pregnant females, patients requiring two or more inotropic agents to maintain blood pressure and patients with acute or chronic kidney injury/failure, were also excluded from the study.

(Continued on next page)
\end{abstract}

\footnotetext{
*Correspondence: ali.shaukat@duhs.edu.pk

${ }^{1}$ Dow College of Biotechnology, Dow University of Health Sciences, Karachi,

Pakistan

Full list of author information is available at the end of the article
}

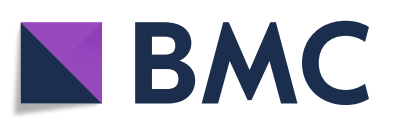

(- The Author(s). 2020 Open Access This article is licensed under a Creative Commons Attribution 4.0 International License, which permits use, sharing, adaptation, distribution and reproduction in any medium or format, as long as you give appropriate credit to the original author(s) and the source, provide a link to the Creative Commons licence, and indicate if changes were made. The images or other third party material in this article are included in the article's Creative Commons licence, unless indicated otherwise in a credit line to the material. If material is not included in the article's Creative Commons licence and your intended use is not permitted by statutory regulation or exceeds the permitted use, you will need to obtain permission directly from the copyright holder. To view a copy of this licence, visit http://creativecommons.org/licenses/by/4.0/. The Creative Commons Public Domain Dedication waiver (http://creativecommons.org/publicdomain/zero/1.0/) applies to the data made available in this article, unless otherwise stated in a credit line to the data. 
(Continued from previous page)

Intervention and comparator: The study consists of four interventions and one comparator arm. All participants receive standard hospital care which includes airway support, anti-viral medication, antibiotics, fluid resuscitation, hemodynamic support, steroids, painkillers, and anti-pyretics. Randomised test patients will receive single dose of CIVIG in following four dosage groups:

Group 1: $0.15 \mathrm{~g} / \mathrm{Kg}$ with standard hospital care

Group 2: $0.2 \mathrm{~g} / \mathrm{Kg}$ with standard hospital care

Group 3: $0.25 \mathrm{~g} / \mathrm{Kg}$ with standard hospital care

Group 4: $0.3 \mathrm{~g} / \mathrm{Kg}$ with standard hospital care

Group 5 (comparator) will receive standard hospital care only

Main outcomes: The primary outcomes are assessment and follow-up of participants to observe 28-day mortality and,

- the level and duration of assisted ventilation during hospital stay,

- number of days to step down (shifting from ICU to isolation ward),

- number of days to hospital discharge,

- adverse events (Kidney failure, hypersensitivity with cutaneous or hemodynamic manifestations, aseptic meningitis,

hemolytic anemia, leuko-neutropenia, transfusion related acute lung injury (TRALI)) during hospital stay,

- change in C-Reactive Protein (CRP) levels,

- change in neutrophil lymphocyte ratio to monitor inflammation.

Randomisation: Consenting participants who fulfill the criteria are allocated to either intervention or comparator arm with a ratio of 4:1, using sequentially numbered opaque sealed envelope simple randomization method. The participant allocated for intervention will be sequentially assigned dosage group 1-4 in ascending order.

Participants will not be recruited in the next dosage group before a set number of participants in one group (10) are achieved.

Blinding (masking): Single blinded study, with participants blinded to allocation.

Numbers to be randomised (sample size): Total 50 patients are randomised. The intervention arms consist of 40 participants divided in four groups of 10 participants while the comparator group consists of 10 patients.

Trial Status: Current version of the protocol is "Version 2" dated $29^{\text {th }}$ September, 2020.

Participants are being recruited. Recruitment started on June, 2020 and is estimated to primarily end on January, 2021.

Trial registration: This trial was registered at ClinicalTrials.gov, NCT04521309 on 20 August 2020 and is retrospectively registered.

Full protocol: The full protocol is attached as an additional file, accessible from the Trials website (Additional file 1).

Keywords: COVID-19, Randomised controlled trial, protocol, passive immunization, anti-COVID19 IVIG, single dose, C-IVIG, convalescent plasma

\section{Supplementary Information}

Supplementary information accompanies this paper at https://doi.org/10. 1186/s13063-020-04839-5.

Additional file 1. Full Study Protocol.

\section{Acknowledgements}

The authors would like to express their gratitude to Dr. Zahid Azam of Dow University Hospital, for his timely and relevant guidance on designing and conducting this clinical trial.

\section{Authors' contributions}

SA, FA, SL, SMM, SMU, MRA and ST were responsible for the study concept and trial design. SL and SQ organized patient recruitment infrastructure. SA, $S L, M B, S K$ and SA were responsible for patient recruitment. SA, SMM, SMU, AA, MK, ES, IA and FA collected and analysed data. SA, SMU, SMM, AA, FA and ASK contributed to protocol drafting and manuscript submission. All authors read and approved the present version of the manuscript for submission.

\section{Funding}

Higher Education Commission (HEC), Pakistan, will be funding the study. HEC has no role in the design of the study and collection, analysis, and interpretation of data and in writing the manuscript.

Availability of data and materials

Not applicable.

Ethics approval and consent to participate

The National Bioethics Committee, Pakistan approved this study protocol on $15^{\text {th }}$ April, 2020 (Ref: NBC-477 COVID19-07) (http://nbcpakistan.org.pk/assets/ covid19-status-2020-(2).pdf). The authors declare that the trial has received ethical approval from the appropriate ethical committee, as described above. All participants sign informed consent by themselves or their legally authorized representatives to participate in the study. 


\section{Consent for publication}

Not applicable.

\section{Competing interests}

The authors declare that they have no competing interests.

\section{Author details}

'Dow College of Biotechnology, Dow University of Health Sciences, Karachi, Pakistan. ${ }^{2}$ Dow University Hospital, Dow University of Health Sciences,

Karachi, Pakistan. ${ }^{3}$ Dow Research Institute of Biotechnology and Biomedical Sciences, Dow University of Health Sciences, Karachi, Pakistan. ${ }^{4}$ Dow

International Medical College, Dow University of Health Sciences, Karachi,

Pakistan. ${ }^{5}$ National Control Laboratory for Biologicals, Islamabad, Pakistan.

${ }^{6}$ Dow University of Health Sciences, Karachi, Pakistan.

Received: 13 October 2020 Accepted: 22 October 2020

Published online: 02 November 2020

\section{Publisher's Note}

Springer Nature remains neutral with regard to jurisdictional claims in published maps and institutional affiliations.

Ready to submit your research? Choose BMC and benefit from:

- fast, convenient online submission

- thorough peer review by experienced researchers in your field

- rapid publication on acceptance

- support for research data, including large and complex data types

- gold Open Access which fosters wider collaboration and increased citations

- maximum visibility for your research: over $100 \mathrm{M}$ website views per year

At BMC, research is always in progress.

Learn more biomedcentral.com/submissions 